\title{
A ANTROPOLOGIA E AS EXPERIÊNCIAS ESCOLARES INDIGENAS
}

\section{ANTHROPOLOGY AND INDIGENOUS SCHOOL EXPERIENCES}

\author{
Clarice Cohn* \\ José Valdir Jesus de Santana**
}

Introdução

Nas últimas décadas do século passado, momento em que a educação escolar é acionada pelos povos indígenas, na relação com o Estado brasileiro, e em que se normatizam e se instituem princípios e características do que deva ser a educação escolar em contexto indígena (nos seus sentidos específico, diferenciado e intercultural), emergem questões que se colocam às escolas indígenas, que atravessam o campo do currículo, a formação de professor, as políticas de financiamento da educação, a concepção de conhecimento próprio a cada povo indígena e, consequentemente, o que pode e deve ser ensinado no espaço escolar. Nesse sentido, os discursos em torno da escola são os mais variados e partem de distintos lugares e de diferentes áreas do conhecimento, a exemplo da Pedagogia, da História e da Antropologia que buscam analisar os impactos da instituição escolar em contextos indigenas.

Todavia, os impactos da "instituição escolar em meio indígena” (GRUPIONI, 2013), em muitos dos casos, são tratados com desconfiança ou quase sempre numa perspectiva ne-

*Doutora em Antropologia pela Universidade de São Paulo; professora Adjunta da UFSCAR (São Carlos/ SP/Brasil) e do Programa de Pós-Graduação em Antropologia Social desta mesma Universidade. Coordenadora do Laboratório de Estudos e Pesquisas em Antropologia da Criança - LEPAC e do Observatório da Educação Escolar Indígena da UFSCAR. clacohn@ufscar.br.

**Doutor em Antropologia Social pela Universidade Federal de São Carlos; professor Adjunto da Universidade Estadual do Sudoeste da Bahia (Vitória da Conquista/BA/Brasil) e do Programa de Pós-Graduação em Relações Étnicas e Contemporaneidade da mesma Universidade. Coordena o projeto de pesquisa intitulado "Os processos de Gestão da Educação Escolar entre os povos indígenas Pataxó, Pataxó Hã Hã Hãe e Tupinambá: experiências em construção”. santanavaldao@yahoo.com.br. 
gativa (a escola é sempre um tipo de vilão que está para desorganizar os modos de produção e transmissão de conhecimentos via tradição) - preocupação muito mais dos antropólogos, por exemplo, do que dos indígenas que recorrem à educação escolar (o que não quer dizer que os indígenas não estejam, nesse processo, refletindo sobre os impactos e as transformações que escola imprime em cada situação ou contexto etnográfico).

As conquistas legais obtidas pelos povos indígenas na luta pelo direito a uma educação escolar diferenciada são muito recentes (GRUPIONI, 2013; PALADINO; ALMEIDA, 2012). A partir da Constituição Federal de 1988, resultou um detalhamento de leis que anunciam e encaminham possibilidades para uma escola indígena específica, diferenciada, intercultural e bilíngue, reconhecendo o direito dos povos indígenas manterem suas identidades étnicas, fazendo uso de suas línguas maternas e processos próprios de aprendizagem. Para além do que o Estado passou a denominar de "escola indígena", buscamos, neste artigo, apresentar distintos "casos etnográficos" em que coletivos indígenas acionam a escola a partir de intencionalidades as mais diversas, informadas por suas epistemologias, regimes próprios de conhecimento e sociocosmologias que, no limite, acabam, por diferentes meios, domesticando a escola e produzindo enfrentamentos e novas demandas para com o Estado. Desta forma, os modos como os indígenas se apropriam da escola produzem aproximações e afastamentos em relação às políticas que o Estado elabora para os povos indígenas, trazem consequências, tensões, desafios tanto para o Estado como para os coletivos indígenas. Refletir em que medida e de que forma tem se dado a construção do diálogo intercultural parece ser extremamente produtivo e necessário porque nos leva a pensar sobre os modos e as formas como a escola tem sido pensada e incorporada em cada contexto, o que é valorizado como conhecimento escolar, quais as tensões que envolvem a produção desse conhecimento, como a cultura é tornada conhecimento e como é produzido o currículo, quem define o que deve ser ensinado e como deve ser ensinado. As reflexões apresentadas aqui são fruto da tese de doutorado ${ }^{1}$ defendida no Programa de Pós-Graduação em Antropologia Social da Universidade Federal de São Carlos.

\section{A escola indígena: princípios e normati- zação da educação em vigor}

A questão da educação escolar entre povos indigenas no Brasil tem uma longa história, que remonta aos tempos colonias, a partir da ação catequética empreendida pelos jesuítas, fruto de uma relação firmada entre a Igreja Católica e o Estado Português. Nesse sentido, "desde sempre, a alfabetização e a educação escolar tiveram um papel importante nessas relações. Jesuitas se esmeraram na catequese dos índios, preparando gramáticas da língua do "gentio" e encerrando crianças em seminários" (COHN, 2005, p. 486). Ainda, conforme Silva e Azevedo (1998, p. 149), “a submissão política das populações nativas, a invasão

1. Agradecemos as contribuições da banca examinadora da tese, composta pelas professoras Dra Susana de Matos Viegas (Universidade de Lisboa); Dra Clarice Cohn (UFSCar); Dra Maria Antonella Imperatriz Tassinari (UFSC); Dra Maria Rosário Gonçalves de Carvalho (UFBA) e ao professor Dr. Felipe Ferreira Vander Velden (UFSCar). Ademais, agradecemos as contribuições dos pareceristas deste artigo. 
de suas áreas tradicionais, a pilhagem e a destruição de suas riquezas, etc. têm sido, desde o século XVI, o resultado de práticas que sempre souberam aliar métodos de controle político a algum tipo de atividade escolar civilizatória”. Esse período corresponde aos dois primeiros séculos da colonização, tendo início com a chegada dos jesuítas, em 1549, e termina com a expulsão destes dos territórios portugueses e espanhóis, em 1759 e 1767, respectivamente (D'ANGELIS, 2012).

Em meados do século XVIII, o Diretório Pombalino (1757) institui mudanças na política do Estado português que reverberam no campo educacional, para a colônia, de forma geral, e para a política educacional destinada aos índios aldeados. Nisso,

A vila pombalina, por natureza e por propósito deliberado, era o instrumento e o espaço físico através dos quais deveria se processar a integração do índio das missões ao universo maniqueísta do mundo colonial. [...] os 95 parágrafos do Directorio compõem um detalhado catálogo de instruções, normas práticas e justificativas que visam, fundamentalmente, transformar o índio das missões, e, eventualmente, os índios tribais, numa grande massa nativa, econômica e socialmente controlada, capaz de suprir, com sua força de trabalho, o esforço de consolidação do domínio colonial português na Amazônia (MOREIRA NETO, 1988, p. 25-26, apud D'ANGELIS, 2012).

0 "Diretório" determinou que haveria duas escolas públicas em cada aldeamento indígena, uma para meninos e uma para meninas, e em ambas deveria se ensinar a ler e escrever. Na prática, as escolas previstas no regulamento contido no Diretó- rio não funcionaram. Em 1798, uma Carta Régia extinguiu o dispositivo do Diretório, salientando a necessidade de integração dos indígenas, "para que os mesmos índios fiquem sem diferença dos outros meus vassalos"2", o que significou o fim de qualquer propósito elevado de um sistema educacional, sendo suficientes os esforços para engajar os povos indígenas nos serviços de interesse dos colonizadores (D'ANGELIS, 2012, p. 20 - 21).

No mesmo sentido, com a instauração do Império,

Ficou tudo como antes: no Projeto Constitucional de 1823, em seu título XIII, art. 254, foi proposta a criação de "...estabelecimentos para a catechese e civilização dos indios...”. Como a Constituição de 1824 foi omissa sobre esse ponto, o Ato Adicional de 1824, art. 11, parágrafo 5, procurou corrigir a lacuna, e atribuiu competência às Assembléias Legislativas Provinciais para promover cumulativamente com as Assembléias e Governos Gerais "...a catechese e a civilização do indígena e o estabelecimento de colônias" (SILVA; AZEVEDO, 1998, p. 150).

Por volta da metade do século XIX, o Império passa a regular a "catequese indígena", através do Decreto 426, de 24 de julho de 1845, contendo o "Regulamento acerca das missões de catequese e civilização dos índios”. Neste regulamento, fica determinado o estabelecimento, em cada Província do Império, do posto de Diretor Geral dos Índios, que entre outras funções deveria recomendar à respectiva Assembleia Provincial “a criação de Escolas de Primeiras Letras para os lugares onde não baste o Missionário para esse ensino"

2. Carta Régia de 12 de maio de 1798 (MOREIRA NETO, 1988, p. 221, apud D’ANGELIS, 2012). 
(Art. $1^{\circ}, \S 18$ ). De fato, da mesma forma que o "Diretório Pombalino", as "Escolas de Primeiras Letras" que deveriam zelar pela "instrução dos indígenas”, conforme o Regulamento do Decreto de 1845 tornaram-se praticamente inexistentes, dado que os governadores provinciais não tinham grandes interesses ou expectativas positivas com relação à escolarizaçãos dos indígenas; além disso, a pobreza de grande parte das províncias inviabilizava recursos para serem direcionados à educação escolar. (D'ANGELIS, 2012).

Com a proclamação da República, não ocorreram alterações significativas no trato com a educação escolar para indígenas. Diante da ineficácia do Estado, a ação de diversas missões religiosas, sejam católicas ou protestantes, continua a ser predominante. Todavia, nesse novo contexto, mesmo predominando ações de caráter missionário, a educação escolar indígena começa a ser pensada/promovida "como política pública [...] com o objetivo de nacionalizar esse contigente da população, através do ensino da língua portuguesa e de permitir sua assimilação à sociedade brasileira. [...] Com essa perspectiva, foi criado em 1910 o Serviço de Proteção aos Índios e Localização de Trabalhadores Nacionais" - SPILTN (TASSINARI, 2008, p. 219-221). Além disso, nesse "novo contexto", a partir da criação do SPILTN, no que diz respeito à educação escolar, tem-se, em certo sentido, maior preocupação com a diversidade linguística e cultural dos povos indigenas (FERREIRA, 2001). "Uma das intenções do governo, naquele início de século XX, era afastar a Igreja Católica da catequese indígena. Outra intenção era fazer os índios adotarem gradualmente hábitos considerados "civilizados" e transformá-los em trabalhadores nacionais" (PALADINO; ALMEIDA, 2012, p. 35). Ademais, segundo Tassinari,

As ações do SPILTN variavam conforme a situação de contato e aliança com a população indígena. A primeira fase de ação frente aos indios considerados arredios ou hostis era denominada "pacificação". Através da doação de bens, agentes do SPILTN procuravam estabelecer os primeiros contatos e "atrair" populações para um território delimitado, as "reservas indigenas", visando iniciar um processo de sedentarização. A segunda fase era propriamente a da "educação", através da implantação de escolas e da fixação dos indígenas num território administrado por um posto indígena. A terceira fase desenvolvia ações para a "civilização" dos indígenas preparando-os para serem "trabalhadores nacionais”. Além da educação escolar visando o ensino da língua portuguesa, e noções de matemática para o comércio, também eram transmitidas técnicas agrícolas, pecuárias e industriais. Uma quarta e última fase previa a emancipação definitiva dos indígenas e sua introdução na "vida civilizada", segundo o ideário positivista (2008, p. 221-222).

A partir da década de 1930, no contexto de uma política nacionalista desenvolvida por Getúlio Vargas, “a política indigenista ancorada na ação catequética do século XIX dá lugar a uma política visando à integração nacional, laica e militarizada" (TASSINARI, 2008, p. 222). Nas duas décadas seguintes, a política desenvolvida pelo $\mathrm{SPI}^{3}$ produziu nova confıguração de aldeamentos indígenas em torno de postos de atração, postos de vigilância e postos indígenas, gerando maior

3. A partir de 1918, o SPILTN passou a ser denominado apenas de SPI. Este órgão foi extinto em 1967, quando foi criada a Fundação Nacional do Índio. 
situação de dependência destas populações em relação aos órgãos de proteção. Nesta nova conjuntura, diante dos processos de sedentarização compulsória dos indígenas, partindo de uma nova relação com o Estado, configurada em termos de dependências ainda maiores com os “órgãos protetores”, a escola deixa de ser um investimento prioritário. “Ao longo dos anos de 1950 e 1960, várias escolas e postos estabelecidos deixam de receber atenção e financiamento, enquanto o SPI se volta para atender as demandas dos conflitos e novas frentes de atração no Sul do Pará" (TASSINARI, 2008, p. 228). Com a extinção do SPI e a criação da Funai, em 1967, ocorrem modificações significativas na educação escolar para índios, sobretudo com a implantação de projetos de ensino bilíngues, uma vez que no discurso da Funai era preciso respeitar os valores tribais.

A partir da década de 1970 surgem projetos alternativos de educação escolar indígena, além de diversas organizações não governamentais voltadas para a defesa da causa indígena, a exemplo da Comissão Pró-Indio de São Paulo, Centro Ecumênico de Documentação e Informação, Associação Nacional de Apoio ao Índio, Centro de Trabalho Indigenista. A partir da ação da Igreja Católica, em sua ala mais progressista, foram criadas duas organizações, a Operação Anchieta, em 1969, e o Conselho Indigenista Missionário, em 1972, com atribuições voltadas para prestar serviços na área de educação escolar para indígenas (FERREIRA, 2001). Nesse mesmo contexto,

Se a educação escolar voltada para os povos indígenas é antiga, secular, a discussão sobre sua adequação às realidades indígenas toma forma a partir da década de 1970 , quando especialistas em diversas áreas, especialmente antropólogos, linguistas e peda- gogos, começam a assessorar na construção de projetos escolares alternativos em algumas escolas indígenas e os movimentos indígenas passam a reivindicar, mais amplamente, o reconhecimento de seus direitos, inclusive o de uma educação formal de qualidade (COHN, 2005, p. 488).

Nesse sentido, a ideia de que a escola poderia ser um instrumento favorável à autonomia indígena e a seus projetos de futuro - e não uma instituição colonizadora começa a ganhar força a partir desse novo cenário. As discussões iniciais enfocavam, quer nos direitos indígenas a uma educação bilíngue, quer na escola como meio de acesso a informações vitais - de caráter econômico, político, linguístico, legal - para os povos indígenas em sua relação com não índios e em sua inserção na sociedade brasileira (LOPES DA SILVA, 2001; FERREIRA, 2001; COHN, 2005; GRUPIONI, 2008; TASSINARI, 2008; CÉSAR, 2011). Da mesma forma,

Nas décadas de 1970 e 1980, tiveram início algumas experiências educacionais de organizações não governamentais que procuravam considerar as especificidades da realidade indígena na concepção do currículo, do calendário escolar, do material didático, da rotina e da disciplina escolar, e no desenvolvimento de metodologias de ensino diferenciadas. Ganhou forca o discurso de que uma escola com esse perfil tinha um sentido libertador, que poderia contribuir para a autonomia dos povos indígenas (PALADINO; ALMEIDA, 2012, p. 38).

Essa mobilização crescente, que demanda pela construção de políticas específicas para os povos indígenas, ganha respaldo jurídico na Constituição de 1988, ou mes- 
mo já na Assembleia Constituinte, quando índios e seus aliados (antropólogos, indigenistas) fazem passar artigos específicos, que regulamentam os direitos diferenciados dos índios. Essa política de reconhecimento, por parte do Estado Brasileiro, da diversidade sociocultural indígena, vai se traduzindo em outros mecanismos legais, referentes a diversos outros aspectos que dizem respeito à saúde das populações indígenas, às políticas de proteção ambiental, dentre outros. Nisso,

Nas últimas décadas do século 20, as lutas e as reivindicações de diversas etnias indígenas pelo reconhecimento de seus territórios e outros direitos resultaram na inclusão de artigos na Constituição Federal de 1988, que busca contemplá-los. Neste sentido, vale ressaltar os artigos 231 e 232, que lhes asseguram o reconhecimento dos direitos sobre os territórios que ocupam, sua organização social, costumes, línguas, crenças e tradições. Esse reconhecimento foi acompanhado de uma série de mudanças relativas à gestão $\mathrm{e}$ à condução das políticas voltadas para essas populações. O governo Collor (1990-1992), logo no início, por meio de decretos assinados em 4 de fevereiro de 1991, atribuiu a diferentes ministérios e órgãos federais responsabilidades antes concentradas na Fundação Nacional do Índio (FUNAI). São eles: o Decreto $\mathrm{n}^{\circ} 23$, que colocou a assistência à saúde das populações indígenas sob a responsabilidade da Fundação Nacional de Saúde (FUNASA); o Decreto $n^{\circ} 24$, que estabeleceu que as ações de proteção ao meio ambiente em terras indígenas seriam coordenadas pela Secretaria do Meio Ambiente (SMA) e executadas pelo Instituto Brasileiro do Meio Ambiente (IBAMA); o Decreto $n^{\circ} 25$, que subordinou os programas e projetos para a autossustentação das comunidades indígena ao Ministério da Agricultura e da Reforma Agrária (MARA); e, finalmente, o Decreto ${ }^{\circ}$ 26, que definiu o MEC como instância coordenadora das ações referentes à educação escolar indígena no País em todos os níveis e modalidades de ensino (BRUNO, 2011, p. 640-641).

As conquistas legais obtidas pelos povos indígenas na luta pelo direito a uma educação escolar diferenciada são muito recentes (cf. GRUPIONI, 2013; PALADINO; ALMEIDA, 2012). A partir da Constituição Federal de 1988, resultou um detalhamento de leis que anunciam e encaminham possibilidades para uma escola indígena específica, diferenciada, intercultural e bilingue, reconhecendo o direito dos povos indígenas manterem suas identidades étnicas, fazendo uso de suas línguas maternas e processos próprios de aprendizagem.

Nos anos 1990, vários documentos e ações surgiram para dar efetividade ao que a Constituição Federal estabelecia. 0 Decreto 26 de 4 de fevereiro de 1991 transfere a responsabilidade da Funai para o Ministério da Educação, no tocante à oferta sobre educação escolar em contexto indígena. Neste mesmo ano, é criada a Coordenação Nacional de Educação Escolar Indígena; além da Coordenação Geral, o MEC institui, em julho de 1992, um Comitê de Educação Escolar Indígena, para contar com a assessoria e a participação dos envolvidos com a questão indígena. Este comitê foi composto por representantes indígenas, representantes de organizações não governamentais, universidades e um representante da Funai. A participação indígena nesse Comitê foi crescendo, no decorrer da década de 1990, transformando-se, em 2001, em Comissão Nacional de Professores Indígenas (GRUPIONI, 2008; PALADINO; ALMEIDA, 2012). 
O Comitê instituído em 1992 elaborou as Diretrizes para a Política Nacional de Educação Escolar Indígena (1993), definindo o que se entende por interculturalidade, determinando o que deve e como deve ser a educação escolar indígena. Foram também elaborados o Referencial Curricular Nacional para as Escolas Indígenas (1998), e os Referenciais para a Formação de Professores Indígenas (2002).

A Lei 9.394/96 - LDBEN - Lei de Diretrizes e Bases da Educação Nacional, institui como dever do Estado a oferta de uma educação escolar bilíngue e intercultural, presentes nos artigos 78 e 79 . No artigo 78 fica garantida a "criação de programas integrados de ensino e pesquisa, para oferta de educação escolar bilingue e intercultural aos povos indigenas, com os seguintes objetivos: proporcionar aos indios, suas comunidades e povos a recuperação de suas memórias históricas, a reafirmação de suas identidades étnicas, a valorização de suas línguas e ciências; e garantir aos indios, suas comunidades e povos o acesso às informações e aos conhecimentos técnicos e científicos da sociedade nacional e demais sociedades indígenas e não indígenas".

O Parecer 14/99 e a Resolução 3/99: o primeiro estabelece as Diretrizes Curriculares Nacionais para a Educação Escolar Indígena, regulamentadas pela Resolução 3/99, que fixa as normas para o funcionamento das escolas indígenas, criando mecanismos para garantir a qualidade da educação diferenciada; o segundo, atribui ao Estado a responsabilidade sobre a educação escolar indígena, em parceria com os Municípios que atenderem a determinadas condições.

A Lei 10.172/01, que institui o Plano Nacional de Educação (em vigor de 2001 a 2010), contém um diagnóstico da educação escolar indígena no Brasil, aponta as diretrizes para a política nacional e estabelece os objetivos e metas a serem cumpridos por estados e municípios. Entre os objetivos e as metas previstos no Plano Nacional de Educação, destaca-se a universalização da oferta de programas educacionais aos povos indígenas para todas as séries do ensino fundamental ${ }^{4}$, assegurando autonomia das escolas indígenas tanto no que se refere ao projeto pedagógico quanto ao uso dos recursos financeiros - o que garante a participação das comunidades nas decisões relativas ao funcionamento dessas escolas (PALADINO; ALMEIDA, 2012). A Lei n. 13.005, sancionada no dia 25 de junho de 2014, aprovou o atual Plano Nacional de Educação (com vigência até 2024), composto por 20 metas, que se relacionam aos diferentes níveis de ensino e modalidades de educação, dentre outras questões. $\mathrm{Na}$ meta 5 do referido Plano, em uma de suas estratégias, fica estabelecido: apoiar a alfabetização de crianças do campo, indigenas, quilombolas e de populações itinerantes, com a produção de materiais didáticos especificos, e desenvolver instrumentos de acompanhamento que considerem o uso da lingua materna pelas comunidades indigenas e a identidade cultural das comunidades quilombolas 5 .

4. Para uma análise crítica em relação ao Plano Nacional de Educação, no tocante à educação escolar indígena, ver D’Angelis (2012), sobretudo no artigo “Olha a educação, indígena!” que compõe o livro Aprisionando sonhos: a educação escolar indigena no Brasil.

5. Em uma das estratégias (6.7) da Meta 6 fica estabelecido: Atender às escolas do campo e das comunidades indígenas e quilombolas na oferta de educação em tempo integral, com base em consulta prévia e informada, considerando-se as peculiaridades locais. A estratégia 7.26, da Meta 7 determina: consolidar a 
A Convenção 169 da OIT, ratificada pelo Brasil em 2004, trata especificamente dos direitos educacionais dos povos indigenas nos artigos 26 e 31 , afirmando que deverão ser adotadas medidas para garantir aos membros dos povos interessados a possibilidade de adquirirem educação em todos os níveis de ensino, pelo menos em condições de igualdade com o restante da comunidade nacional. Salienta ainda, que o Estado deve assegurar medidas de caráter educativo em todos os setores da comunidade nacional e assegurar a correta abordagem da temática indígena nas escolas e nos livros didáticos ${ }^{6}$.

0 Decreto 6.861/2009 cria os Territórios Etnoeducacionais. Com o Decreto, o MEC propõe que se faça uma articulação entre os entes Federativos a partir de uma pactuação que deve ser efetivada em um Plano de Ação. Para o MEC, os governos estaduais/municipais devem elaborar um plano de ação articulado com vários sujeitos sociais, indígenas, universidades e entidades de apoio, para oferecer a Educação escolar indígena, observada a sua territorialidade e respeitando suas necessidades específicas. Por fim, a Resolução no 5, de 22 de junho de 2012, que define as Diretrizes Curriculares Nacionais para a Educação Escolar Indígena na Educação Básica, dentre outras coisas, estabelece os objetivos da educação escolar indígena, determina seu modo de organização, caracteriza princípios que devem orientar os projetos políticos pedagó-

educação escolar no campo de populações tradicionais, de populações itinerantes e de comunidades indigenas e quilombolas, respeitando a articulação entre ambientes escolares e comunitários e garantindo: o desenvolvimento sustentável e preservação da identidade cultural; a participação da comunidade na definição do modelo de organização pedagógica e de gestão das instituições, consideradas as práticas socioculturais e as formas particulares de organização do tempo; a oferta bilingue na educação infantil e nos anos iniciais do ensino fundamental, em lingua materna das comunidades e em lingua portuguesa; a reestruturação e a aquisição de equipamentos; a oferta de programa para formação inicial e continuada de profissionais da educação; e o atendimento em educação especial. A estratégia 7.27, desta mesma meta assegura: desenvolver curriculos e propostas pedagógicas específicas para a educação escolar para as escolas do campo e para as comunidades indigenas e quilombolas, incluindo os conteúdos culturais correspondentes às respectivas comunidades e considerando o fortalecimento das práticas socioculturais e da língua materna de cada comunidade indígena, produzindo e disponibilizando materiais didáticos específicos, inclusive para os (as) alunos (as) com deficiência. A Meta 10, em sua estratégia 10.3 estabelece: fomentar a integração da educação de jovens e adultos com a educação profissional, em cursos planejados, de acordo com as características do público da educação de jovens e adultos e considerando as especificidades das populações itinerantes e do campo e das comunidades indígenas e quilombolas, inclusive na modalidade de educação a distância. A Meta 11, na estratégia 11.9, determina: expandir o atendimento do ensino médio gratuito integrado à formação profissional para a população do campo e para as comunidades indigenas e quilombolas, de acordo com os seus interesses e necessidades. Por fim, na Meta 12, na estratégia 12.13 fica determinado: expandir atendimento especifico a populações do campo e comunidades indigenas e quilombolas, em relação a acesso, permanência, conclusão e formação de profissionais para atuação nessas populações.

6. Em 2008, em consonância com o artigo 31 da Convenção 169 da OIT, o presidente Lula promulgou a Lei 11.645, que instituiu a obrigatoriedade do ensino da História e da Cultura Indígena nos sistema de ensino público e privado; cabe ressaltar que a referida Lei altera a 10.639, de 2003, que tornou obrigatório o ensino de História da África e da Cultura Afro-Brasileira, nos sistemas de ensino de todo o país sejam eles público ou privado. 
gicos das escolas indígenas, concepções de currículo, práticas de avaliação, processos de formação e de profissionalização dos professores indígenas, além de definir as competências que cabem aos entes federados no que se refere à responsabilidade e garantia da educação escolar indígena, através do regime de colaboração.

De forma geral, toda a legislação (marcos legais e conceituais) produzida nesse último período garante: o uso das línguas maternas no processo escolar; o recurso a processos próprios de aprendizagem; educação intercultural, com acesso a língua nacional e a conhecimentos ditos universais; participação de grupos indígenas no planejamento e execução de programas; adoção de currículos próprios com o conteúdo cultural de cada grupo; materiais didáticos específicos e diferenciados; autonomia pedagógica e financeira das escolas; formação de professores indígenas e programas específicos para a melhoria das condições de ensino; direito de criar suas próprias instituições de ensino, entre outros $^{7}$ (GRUPIONI, 2008; BRUNO, 2011).

\section{Interculturalidade, escolas indígenas e seus modos de apropriação}

Parece-nos importante refletir sobre 0 que se tem denominado de educação escolar indígena específica, diferenciada e intercultural, a partir dessas novas exigências e demandas que são colocadas pelos povos indígenas. Cabe-nos, ademais, pensar como as questões relativas à diversidade, $\dot{a}$ diferença, $\dot{a}$ cultura e à identidade têm sido tratadas nas reflexões sobre os alcances e limites para a construção do fazer pedagógico informado pela perspectiva intercultural $^{8}$. É preciso, segundo Collet (2006b, p. 126) "documentar e avaliar como as ideias ou a retórica da interculturalidade são traduzidas na prática, tanto nos cursos de formação de professores como no dia-a-dia da experiência escolar indígena". No mesmo sentido, cabe-nos indagar, como nos adverte Sampaio (2006, p. 166)

Como nesses diálogos e disputas sabidamente desiguais, e através de que canais de poder e de que recursos simbólicos, se produzem e

7. Atualmente, os órgãos responsáveis pela educação escolar nas aldeias são o MEC, a Secretaria de Educação Continuada, Alfabetização, Diversidade Inclusão (SECADI/MEC) - que responde pelas políticas de formação de professores indígenas voltadas para a oferta das licenciaturas e do magistério intercultural e pela produção de materiais didáticos e paradidáticos específicos - e, finalmente, a Comissão Nacional de Educação Indígena (CNEI). Os recursos financeiros provêm do Fundo de Manutenção e Desenvolvimento da Educação Básica e de Valorização dos Profissionais da Educação (FUNDEB), do Fundo Nacional de Desenvolvimento da Educação (FNDE), do Programa Dinheiro na Escola (PDE) e do Programa Nacional de Alimentação Escolar (PNAE).

8. Celia Collet (2006) faz uma reflexão importante acerca da interculturalidade e de como o conceito surge, no contexto da educação voltada para povos indígenas, a partir dos Estados Unidos, em fins do século XIX e início do século XX; além disso, a autora apresenta uma discussão, de caráter histórico, no sentido de demonstrar com a ideia de interculturalidade vai sendo disseminada a partir do México para a América Latina, sob a influência do Summer Institute of Linguistics (e seus desdobramentos no Brasil). Por fim, é feita uma discussão de como a interculturalidade vai sendo pensada no continente europeu, a partir das políticas educacionais que se voltam para pensar as questões relacionadas à diversidade cultural, tendo como foco central o atendimento às minorias, e a entrada de imigrantes oriundos das antigas colônias europeias. 
se legitimam, para todo o campo da educação escolar indígena - e mesmo para mais além dele-, as definições do que sejam especificidade e diversidade culturais indígenas $\mathrm{e}$ do que podem estas, enfim, estar a significar para cada um dos pólos e no contexto da relação entre esses.

A utilização de termos como diversidade cultural, diferença, especificidade, identidade, cultura e resgate cultural em muitos dos discursos educacionais e, da mesma forma, em muitos projetos de educação escolar indígena no contexto contemporâneo, ainda estão impregnados de uma visão “etnocêntrica e distante da produção de um real diálogo cultural com as posições indigenas" (SAMPAIO, 2006, p. 167). Gomes (2012, p. 11) nos adverte que "o desafio da ideia de interculturalidade pode nos levar a retomar os termos do debate a partir da noção mesma de cultura, caminho que poderia ser promissor em nossas reflexões". Se por um lado, o conceito de interculturalidade instaura e produz impactos nas políticas educacionais contemporâneas, tanto as voltadas para contextos indígenas como para contextos não indígenas, diversos autores, da antropologia, da educação e de outras áreas do conhecimento têm se dedicado a uma reflexão mais crítica acerca desse conceito e dos resultados, teóricos e práticos, que se desdobram nos modos como a educação é instituída como política pública e como política indígena. Nisso, segundo Paladino e Czarny (2012, p. 14-15),

Vários autores criticam o fato de as propostas de educação intercultural se preocuparem principalmente com a dimensão da diferença e se esquecerem da desigualdade das relações de poder e dominação às quais as minorias étnicas, raciais, de gênero e nacionais estão submetidas, o que contribuiria para a repro- dução de uma estrutura social discriminatória. [...] Desse modo, o campo da pesquisa em antropologia e educação se vê confrontado, na América Latina - tal como ocorre em outras discussões sobre povos indígenas -, com a tensão analítica e política de conceber a escola como instituição colonizadora e assimilacionista ou como instituição possibilitadora de cidadania e transformação.

Por outro lado, como bem alerta Giraldin,

0 que temos observado na universalização do acesso à escolarização entre os povos indígenas no Brasil é que a escola "diferenciada e específica” ocorre principalmente com o ensino da língua materna, arte e cultura. No restante da organização, administração, calendário, conteúdo, ela segue toda a lógica disciplinadora de formação do habitus da escola não-indígena (estrutura física e organizacional), que se estende para as escolas indígenas (2010, p. 55).

Maria Aparecida Bergamaschi (2012), ao refletir sobre a interculturalidade nas práticas escolares indígenas, pergunta em que medida a escola indígena vem se constituindo como um lugar da interculturalidade e de que forma este conceito é apropriado pelas políticas públicas, pelo Estado brasileiro e qual o reflexo na elaboração nos documentos oficiais que normatizam e instituem uma educação escolar indígena na perspectiva da interculturalidade. Segundo a autora, parece haver uma contradição, pois, ao mesmo tempo em que se reconhece a pluralidade cultural, a diversidade de escolas indígenas e as mais variadas intenções que envolvem a construção de escolas indígenas no contexto de diferentes povos, produz-se uma normatização (tal como Lopes da Silva [2001] já anunciava). De toda sorte, segundo a auto- 
ra, é preciso compreender a escola indígena como sendo construída, a partir do diálogo intercultural, tanto internamente, "ou seja, a interação entre os modelos tradicionais de educação e a educação escolar, quanto como possibilidade de diálogo entre duas diferentes sociedades e culturas: a indígena e a não indígena” (BERGAMASCHI, 2012, p.48).

Desde os trabalhos de Meliá (1997) e Lopes da Silva (1998), muitas das reflexões em torno da educação escolar em contexto indígena têm sido elaboradas tendo como seu contraponto a chamada educação indígena ou educação tradicional, sempre no sentido de marcar diferença entre os modos como cada povo indígena transmite seus conhecimentos, suas tradições, a partir de uma "pedagogia própria”, que independe da escola e das formas como esta produz e transmite conhecimento. Nesse sentido, não é difícil encontrar, entre os estudiosos da temática, essa distinção. Geralmente, a questão é abordada da seguinte forma: os povos indígenas sempre tiveram formas de educação, por meio das quais puderam transmitir seus conhecimentos, seus saberes e experiências às gerações mais novas e, para isso, não precisaram da educação escolar; a educação escolar, portanto, é sempre pensada como uma instituição exógena às comunidades indígenas; nesse debate, se instaura certa dicotomia e não são raros os alertas sobre os perigos que a escola pode produzir no contexto das comunidades indígenas, sobretudo em relação àquilo que a educação indígena sempre produziu. Muitos desses alertas são, de fato, reais. Contudo, como já nos alertou Tassinari (2001), é preciso problematizar essa relação.

Parece-nos que a entrada da escola em certos grupos indígenas, a exemplo dos Tupinambá de Olivença (SANTANA, 2015), tem produzido reflexões importantes acerca do que seria a "educação indígena" ou a "educação tradicional”. Como consequência, a educação escolar em sua perspectiva diferenciada e intercultural tem produzido sentidos para o que costumamos chamar de educação tradicional e, dessa forma, a escola Tupinambá (e muitas outras escolas indígenas) parece produzir um tipo de "educação tradicional”, na medida em que elabora outros discursos sobre o que é a escola e sua importância e, consequentemente sobre suas tradições, cultura e educação (SANTANA, 2015). É uma construção cultural, no sentido dado por Tassinari (2003), quando esta busca compreender o processo de construção cultural das famílias Karipuna do Amapá.

De certo modo, a dicotomização de educação indígena e educação escolar indígena, a qual foi muito importante para a instituição de uma escola respeitosa das especificidades indígenas, também acaba por produzir uma polarização, como se houvesse, sempre, dois contextos completamente diversos, e mais ou menos complementares a depender do projeto de escolarização, se este for mais ou menos próximo daquele (COHN, 2015), e que se reforça com a própria normatização da Educação Escolar Indígena. É como se voltássemos a um purismo, como se a educação indígena fosse sempre anterior à escolar. 0 caso Tupinambá é privilegiado para se recolocar esta questão (SANTANA, 2015), tendo em vista que a escola é parte inerente à construção de parentes e de cultura, de memórias e de espaços - ou, colocando de outro modo, dos "princípios estruturantes da socialidade” Tupinambá (VIEGAS, 2007).

A escola indígena produz certo tipo de tradição indígena e de educação e, do mesmo modo, tradições indígenas, quando tornadas públicas (tanto interna a cada contexto indígena, quanto externamente, na relação com o Estado e com outras alterida- 
des) produzem certo tipo de escola com suas diferentes demandas, disputas e tensões.

Se para muitos antropólogos e estudiosos da questão indígena, a chegada da escola em tais contextos pode trazer perigos à educação tradicional, aos modos próprios de transmissão de conhecimento, é verdade, também, que em muitos desses contextos a escola tem servido para produzir "conhecimento tradicional", mesmo que com aspas, um conhecimento objetificado, como aponta Dal' Bó (2010) em sua discussão sobre o "conhecimento tradicional" que passa a ser elaborado e acionado por estudantes indígenas que ingressam na Universidade Federal de São Carlos. Também é certo que, em muitas situações, os discursos relacionados aos conhecimentos tradicionais e à educação tradicional têm sido elaborados a partir do que o Estado normatizou como sendo educação escolar indígena específica, diferenciada e intercultural.

Por outro lado, diversos contextos etnográficos têm nos mostrado que diferentes povos indígenas querem suas escolas iguais às escolas dos não índios, contrariando a legislação em vigor sobre educação escolar indígena específica, diferenciada e intercultural, como demonstram Tassinari (2003) em sua etnografia sobre os Karipuna, Cohn (2005) e Beltrame (2013) em suas etnografias sobre os Xikin. 0 certo é que não podemos falar em um único modelo de escola indígena nem tampouco pensar num único modelo de escola diferenciada. Quem, de fato, tem que definir o tipo de escola que deseja são os próprios indígenas, seja ela "mais" ou "menos" diferenciada.

Em meio a esse novo contexto, em que se busca construir projetos de educação escolar na perspectiva da diferença, da especificidade e interculturalidade, surgem outras questões, teóricas e práticas, de ordem polí- tica e cultural, que reverberam nos modos e nas formas de entendimento do que seria uma educação escolar, em contexto indígena, assentada nesses novos princípios. Lopes da Silva (2001) já colocara a necessidade de aliarmos, em nossas reflexões sobre educação escolar indígena, as contribuições teóricas e analíticas que a antropologia e a etnologia sul-americanas contemporâneas têm produzido, com as questões que dizem respeito à relação entre a antropologia e a educação. No limite, os desafios que se colocam seriam da seguinte ordem: como compreender os projetos de educação escolar indígena em nosso país a partir dos conhecimentos e categorias analíticas que têm sido produzidos no campo da etnologia, que pouco tem dialogado com as questões de educação? Como nos lembra Lopes da Silva (2001, p. 40),

A etnologia do pensamento indígena, que revela a complexidade das proposições ontológicas e metafísicas ameríndias e sua originalidade flagrante perante o pensamento ocidental (ilustra-o o perspectivismo amazônico), alerta para a complexidade das questões com que terão de tratar experiências de educação escolar que se desejem efetivamente respeitosas dos direitos indígenas.

No contexto atual, compreender os modos como os próprios indígenas refletem sobre a escola e se relacionam com ela, bem como a execução das políticas públicas destinadas a essa área e a atuação dos profissionais que trabalham diretamente neste local, sejam eles indígenas ou não, para tentar entender as possibilidades de arranjos dessas relações, é tarefa que vale a pena investigar e para isso a antropologia tem muito a contribuir (BELTRAME, 2013). No mesmo sentido, como afirma Beltrame, 
Com a intenção de problematizar os discursos que são feitos em torno do tema e compreender a relação que os indígenas constroem com suas escolas, recentes trabalhos na área da antropologia tem se preocupado em mostrar como a diversidade étnica desses povos reflete na maneira como cada um se apropria da escola e, acima de tudo, como os indígenas produzem reflexões sobre esta instituição. Baseados em concepções e cosmologias próprias, elaboram expectativas diferentes sobre esse espaço, o modo como ele deve funcionar e o que pretendem conseguir ao aceitá-lo em seu meio e inseri-lo no cotidiano. As soluções encontradas pelos indígenas para decidir o lugar que esta instituição, de origem externa, deve ocupar na vida do grupo e na relação com outras esferas sociais não cabem, assim, dentro de um modelo fechado (2013, p. 18-19).

Para Mainardi (2010), a escola entre os Tupi Guarani da terra indígena Piaçaguera - SP, exerce um papel importante no resgate cultural de seu povo, a partir das relações que articula com seus outros - Guarani Mbya, os não indígenas e outros indígenas. A escola, segundo Mainardi, tem papel importante, na medida em que se torna o local de ensino da língua e da cultura às crianças. Nesse sentido, a "escola e a casa de reza são locais de negociação, onde ocorre constante atualização/construção do conhecimento e do que pode ser Tupi Guarani” (2010, p. 53). Do mesmo modo, segundo a autora,

A atualização-articulação do conhecimento do que é tido como tradicional, da língua, da reza, das histórias, e de quem são seus deten- tores perpassa o ambiente escolar. Este é um espaço, tal como a casa de reza, de negociação do que pode ser Tupi Guarani. [...] A escola Tupi Guarani adquire, nesse cenário, diversos papeis, ela é tanto marcadora de diferenças e da particularidade tupi guarani, como o espaço no qual conhecimentos não indígenas devem ser ensinados; é o local onde podem resgatar a cultura, mas não deixa de ser atravessadas pelas relações que constroem, constantemente, conhecimento e tradição (MAINARDI, 2010, p. 54-55).

No limite, e essa é a discussão que Mainardi faz em sua dissertação de mestrado, ao buscar compreender as relações que atravessam o ambiente escolar Tupi Guarani (mas não somente este ambiente) e que envolvem os Guarani Mbya, Tupi e não indígenas e ainda as relações entre eles próprios, “articulam disposições políticas, a proximidade e o distanciamento entre parentes e os que são considerados conhecedores de algo" (2010, p. 55), acabam por definir o que pode ou não ser considerado como Tupi Guarani, e isso implica a construção de redes de relações que atualizam conhecimentos e sujeitos, define o que é a tradição, a quem pertence determinados conhecimentos, produz a pessoa Tupi Guarani, sempre em relação a seus outros.

Vieira (2010) analisa a relação entre saber xamânico e educação escolar, sugerindo que, assim como os cantos rituais são usados para pacificar os espíritos, a escrita é usada para pacificar os brancos. Se os Maxakali podem imitar os cantos e ritos ensinados pelo próprio yãmiy ${ }^{9}$ para pacificá-los, podem também usar a escrita e a es-

9. Os yãmiy são agrupados pelos Maxakali em diferentes yãmiyxop (xop-grupo). [...] Durante os rituais taxtaxkox (lagarta da taquara) de iniciação masculina, os meninos são capturados por espíritos e passam um mês em reclusão no Kuxex ('casa de religião', no português falado pelos Maxakali. Local frequentado ape- 
cola para pacificar o branco. No limite, segundo Vieira, os Maxakali vêm utilizando a escola e a escrita para a produção, num primeiro momento, de um conhecimento sobre os brancos e, num segundo momento, de um discurso para os brancos (VIEIRA, 2010, p. 146-148). Nisso, segundo a autora,

Os Maxakali utilizam metáforas do contexto xamânico para compreender o processo de ler escrever. São feitas várias analogias entre escrita e canto, a começar pela tradução literal da palavra 'escrever' em Maxakali. $\mathrm{Ka}$ xambix significa, literalmente, "desenhar o canto. [...] Os Maxakali comparam frequentemente a escola ao kuxex, pois ambos são lugares próprios à transmissão do conhecimento advindos do exterior (a escrita vem dos brancos e os cantos vem dos yãmiy) (VIEIRA, 2010, p. 144).

Ademais, segundo Vieira (2010), se os cantos e mitos continuam sendo ensinados de forma 'tradicional', nas casas e durante os rituais, a lição mais importante apreendida por professores e alunos das escolas Maxakali é como lidar com a burocracia que se dá via escrita - e, por consequência, como 'pacificar' os brancos, fazendo-os passar de potenciais agressores a aliados. A guerra ${ }^{10}$, cuja prática teria se tornado, atualmente, quase impossível, é atualizada no plano da cosmologia, do pensamento, nos contextos do ritual e da escola. Alvarez (2004, p. 74) aponta que, ao socializarem o conhecimento xamânico nas "aulas de cultura”, os Maxakali elegeram essa dimensão para constituírem sua imagem para o "outro". A dimensão ritual amplia o seu campo semântico para dar sentido às relações escolares também, relações essas que se constituem através dos "brancos", esses outros extremos.

Peter Gow (1997, 2010, 2006), a partir de sua etnografia sobre os Piro, no Peru, traz importantes reflexões acerca de como as comunidades nativas do Baixo Rio Urubamba pensam a escola a partir da lógica do xamanismo e do parentesco. Conforme Tassinari (2001, p. 59) "Gow mostra como a escola, inicialmente uma instituição alheia às populações nativas do Baixo Urubamba, passou a ser parte integrante e fundamental de seu modo de vida e foi incluída nas suas explicações sobre o mundo e as relações de parentesco". Segundo Gow (1997, p. 62), para os Piro, trata-se disso: "viver longe dos parentes é "esquecer-se" deles, e todo esquecimento entre parentes leva ao ressentimento e, em última análise, à fragmentação das aldeias”. Ainda, segundo Gow,

nas por homens, por onde os espíritos devem passar ao entrar ou sair da aldeia), aprendendo sobre os yãmiy. Cada grupo de parente está ligado a um grupo de yãmiy. Aqueles que frequentam um mesmo Kuxex e sempre realizam rituais juntos são chamados xape (parentes) e possuem o conhecimento de determinado conjunto de práticas rituais e cantos. Este repertório é um patrimônio familiar passado de geração para geração. Um canto é sempre propriedade de um vivente, mas esta propriedade é compartilhada com um yãmiy (VIEIRA, 2010, p. 139-139). Cf. também Alvarez (1992).

10. Os Maxakali atuais parecem ter herdado uma memória a respeito de relações com inimigos tradicionais mobilizada hoje para mover uma guerra atualizada na forma de disputa pela 'autenticidade' indigena' alcançada através da prática ritual e do uso da língua, e propagandeada através dos CDs e livros de cantos e histórias em língua vernácula produzidos no âmbito da escola indígena ou de projetos de pesquisa e extensão das universidades (VIEIRA, 2010, p. 37). 
Ao evocar a escola e a Comunidad Nativa como base para a ação comunitária, eles evocam, simultaneamente, por contraste, as vidas de seus ancestrais, que viveram na floresta. Especialmente eles evocam as narrativas de escravidão e opressão sofridas por seus ancestrais e por alguns parentes mais velhos. Os ancestrais foram escravizados pelos brancos e seus descendentes viveram e trabalharam em sistema de débito ("barracão") nas haciendas. Os mais velhos viveram essa experiência de violência e as "aldeias reais" de hoje foram vitórias obtidas frente à oposição dos patrões brancos. Cada referência à escola e à Comunidad Nativa ressoa contra a narrativa de violência e opressão. Para os nativos, "ser civilizado" não é oposto a uma cultura idílica "tradicional" que vem se perdendo, mas sim se opõe à ignorância e ao desamparo dos antigos ancestrais moradores da floresta. Ser "civilizado" é ser autônomo, viver em aldeias de acordo com os valores dos próprios nativos, ao invés de viver dos caprichosos desejos de um patrão. [...] 0 idioma do parentesco permeia toda a sua linguagem, a escola e a Comunidad Nativa são idiomas de parentesco, quando vistas de dentro da cultura nativa. [...] A constante evocação do passado nas vidas dos nativos deve ser referida a seus próprios valores. Para as pessoas nativas, a história é o parentesco. A história não é experimentada como uma força que vem de fora para corromper uma estrutura atemporal de deveres e obrigações de parentesco. As relações de parentesco são criadas e dissolvidas no tempo histórico que confere significados e influências para os nativos ao serem estruturadas pelas relações de parentesco (2006, p.188-189).

Silva (2010) reflete sobre a importância da escola entre os Xerente, as formas da interculturalidade praticadas na e pela escola a partir das práticas dos professores deste povo. Segundo a autora, o professor Xerente "age como um agente ativo e criativo, buscando formas de ensinar em uma escola formal e fazendo ponte com o conjunto de símbolos de sua cultura, defronta-se com o sistema de educação nativo, não formal e não livresco" (SILVA, 2010, p. 30). A escola, através de diversas práticas, a exemplo da documentação da cultura Xerente, vem promovendo eventos, filmando a corrida de toras entre alunos de várias escolas, uma vez que através da corrida de toras são acionados os sistemas de parentesco e o de classifıcações clânicas. No âmbito escolar, ademais, são utilizadas as pinturas clânicas, em corpos desenhados no caderno ou na lousa e por meio destas chega-se ao sistema de parentesco, de clãs, da organização social tradicional, ao entendimento das mudanças operadas em função do contato com a sociedade nacional. Nisso, "ao acionar esses conteúdos em sala de aula, o professor está acionando uma relação dos alunos com sua cultura e com sua história”. Dessa forma, "a escola 'ensina' e reproduz uma ordem social tradicional $^{11}$ " (SILVA, 2010, p. 30).

Melo e Giraldin (2012) refletem sobre a educação escolar entre os Xerente e, diferentemente de Silva (2010), apresentam uma série de contradições e possíveis problemas

11. "O interessante é justamente o fato de esse processo passar pela escola, e da apropriação desta como lugar por excelência da resistência cultural, combinada com a aquisição de habilidades para preparar as crianças para o face a face com os não índios. Essas habilidades passam, para eles, claramente pelo domínio da língua portuguesa, da leitura e da escrita” (SILVA, 2010, p. 36). 
que têm surgido a partir da escola, apesar do grande interesse que os Xerente têm por ela. Segundo os autores, são comuns entre os Akwe as estratégias que visam domesticar, ou, em outras palavras, trazer para o "mundo Xerente" sujeitos ou elementos estrangeiros. É dentro dessa lógica que bens de consumo como bicicletas, fogões, panelas e outros objetos têm sustentado a rede de bens e circulação de dádivas construídas nas ocasiões de cerimônias fúnebres, de nominação e matrimoniais ganhando, portanto, um novo sentido (MELO e GIRALDIN, 2012, p. 181-182). Dessa forma, e tendo em vista que é através da relação com o exterior, com a alteridade, que se alimenta o socius Akwe, que a escola vai sendo incorporada e domesticada, não sem contradições.

A presença da escola na aldeia suscita diferentes e, por vezes, contraditórias expressões de sentimentos. A mesma escola que é reivindicada e vista como um meio de conquistar melhores condições de vida e como uma oportunidade para conhecer melhor o mundo dos brancos, para dele se apropriar e/ou defender, é mal vista por tirar as crianças e os jovens do convívio familiar e ensinar mais coisas dos brancos que dos Akwe, afastando, assim, os mais jovens da cultura que lhe é própria (MELO; GIRALDIN, 2012, p. 183). Ao mesmo tempo em que enfatizam a importância da escola, parecem olhá-la com desconfiança. Portanto, são muitas as dificuldades vivenciadas por alunos e professores, que extrapolam a perspectiva unicamente pedagógica; tais dificuldades, surgidas em contexto escolar, vão de encontro a noções Akwe de pessoa, corpo e conhecimento, noções estas que impactam a "forma escolar", a lógica pedagógica, os processos de construção do conhecimento e o que se espera em termos de relação e atitude dos estudantes em sala de aula. Se a escola, ao menos a partir de sua lógica ocidental, espera estudantes com postura "ativa" e "interessada" em sala de aula, questionadora, não é isso que ocorre nas salas de aula com estudantes Akwe. Entre os Akwe, ensinar e aprender são faces de um mesmo processo que começa desde muito cedo. Mais que aprender, é necessário aprender a aprender, ser um bom aprendiz. Nesse processo de aprendizagem, a audição prevalece sobre a fala. Por isso mesmo, as perguntas são raras. Isso não quer dizer que o falar não possua importância no processo de ensino-aprendizagem, mas sim que a palavra é geralmente posse daquele que tem mais conhecimento. A escola, para os Akwe, ao mesmo tempo que desejada, parece constituir um espaço estranho, sempre sob suspeita, sobretudo pelas gerações mais velhas (MELO; GIRALDIN, 2012, p.191). Desse modo, segundo os autores,

Fica claro que estudos em torno das categorias Xerente de pessoa, corpo e conhecimento são de fundamental importância para que se possa de fato mensurar os reais efeitos do processo de escolarização, que avança, entre os Xerente a passos largos. Afinal, para que a escola em meio indígena seja capaz de atender às expectativas e demandas de cada povo, as atenções devem estar centradas nas perspectivas indígenas de educação, e não o contrário (2012, p. 195).

Se a escola, entre os Bakairi, parece, em um primeiro momento, estar completamente alheia aos processos e ao contexto "tradicionais" nativos de aprendizagem, pois os Bakairi fazem questão de que ela seja "como a do branco" e para isso se esforçam em copiar a disciplina, as maneiras, o conhecimento das "coisas da cidade", Collet (2006, 
p. 272) defende que, para eles, que forjam sua identidade a partir da "transformação" em "outro”, esta instituição deve ser a mais parecida possível com a escola não indígena porque seria o contrário que constituiria discriminação. Todavia, ela acrescenta:

[...] No cotidiano, aparentemente tem-se uma escola não-diferenciada, o oposto do que seria pensado como escola indígena. [...] É exatamente ao pretender 'ser como o outro', no 'civilizar-se' pela escola, que os Bakairi visam se reproduzir enquanto um grupo diferenciado, tendo o parentesco como fundamento organizacional e valor maior. A escola, em vários sentidos e níveis, funciona como o $\mathrm{ka}$ do: pelo seu destaque enquanto instituição pública; por ser meio de captura de recursos pertencentes a 'mundos outros', essencial à reprodução das famílias; por seu funcionamento depender de especialistas com conhecimento dos códigos do 'outro', aprendido durante um período de reclusão; por recorrer a performances coletivas que envolvem práticas que visam 'transformar' o kurâ/Bakairi em 'outro' (COLLET, 2010, p. 183).

Nunes (2010) apresenta, a partir de sua etnografia do momento da construção de uma escola na Aldeia Xavante Idzö $u h u$, no Mato Grosso, o empenho de professores para o funcionamento da escola e, da mesma forma, os diversos entendimentos que pais e mães têm acerca da escola e das propostas educacionais dos professores, que variam desde os que "não tem opinião consistente formada a respeito do assunto. Há os que entendem, mas não opinam, há os que desconfiam, os que gostam, os que não entendem, mas estão a favor, os que são contra, os que estão atentos ao que acontece e os que não querem saber de nada" (NUNES, 2010, p. 100). Para os professores, de forma geral, a escola é considerada como um espaço para sistematização de conhecimento e cultura, através do aprendizado da leitura e escrita. Além disso, é preciso considerar outras questões que precisam ser resolvidas, como por exemplo,

[...] Organizar um calendário e um horário escolares que, para além de garantir que se cumpram as exigências da educação escolar ofıcial, considere a participação das crianças nas atividades domésticas e produtivas, do dia-a-dia ou sazonais, pois esta participação tem importância fundamental nestas sociedades em termos educativos, económicos, sociais e culturais. [...] Ainda que supostamente diferenciada, é a escola, como instituição universal e homogeneizadora que tende a prevalecer. [...] 0 papel de professor acarreta, ainda, outras dificuldades: ambos os atuais professores da escola são já considerados homens maduros, com filhos e filhas prestes a casar e, portanto, tendo que obedecer a uma série de regras de evitação que têm raiz na estrutura social dual baseada em metades exogâmicas. Estes professores não podem olhar frontalmente, conversar ou dirigir diretamente a palavra às meninas que virão a ser suas noras. 0 mesmo acontece com seus futuros genros. Como será possível conduzir uma aula e, simultaneamente, atentar para especificidades socioculturais tão sutis e relevantes? (NUNES, 2010, p. 106).

Souza (2001) faz uma etnografia da escola dos Pataxó de Barra Velha, pensando -a, do ponto de vista teórico e analítico, a partir da aproximação entre Antropologia e Educação ou, como diz a própria autora “o problema em que me defronto é o da [...] possibilidade de dialogar e incorporar uma abordagem antropológica da educação escolar indígena (SOUZA, 2001, p. 38). 
A escola, para os Pataxó de Barra Velha, se constitui como espaço privilegiado de afırmação da identidade étnica, de fortalecimento cultural, de atualização da memória e da história, de aprendizado da língua Patxoha $\tilde{a}^{12}$ por meio de diferentes mecanismos e a partir de diversos sujeitos, a exemplo dos professores, anciãos, pais, estudantes e comunidade. Se diversos sujeitos participam desse processo, segundo Souza, os professores ganham destaque privilegiado ou estão entre os mais importantes interlocutores, "convertendo-se em promotores do resgate étnico”. Desde quando passaram a lecionar, os professores indígenas começaram um processo de reflexão geral no interior de sua categoria profissional, a qual, organizada em ações culturais, passa a reexaminar seu próprio papel, e sua condição sociocultural e política na comunidade; são esses mesmos professores que estimulam os mais velhos a participarem do ensino diferenciado. Dessa forma,

Os professores indígenas têm assumido, assim, um papel fundamental no novo sistema educativo. São hoje os responsáveis por di- rigir a aplicação de um modelo de educação intercultural, em função do qual, apesar de não terem ainda suficiente preparação, promovem o desenvolvimento do sentimento étnico no grupo, ao realizarem a mediação entre a sociedade nacional e a comunidade indígena. Por meio da seleção dos elementos significativos da autoctonia, os professores contribuem, de uma maneira nova, para a definição da identidade étnica. Através das aulas, no bojo do ensino diferenciado, a cultura pataxó, a identidade do ser pataxó torna-se objeto de conhecimento escolar (SOUZA, 2001, p. 50).

Chates $(2011,2013)$ em sua etnografia sobre a escola Kiriri, busca analisá-la a partir da ideia de domesticação ${ }^{13}$, utilizando tal noção diante do entendimento de que a apropriação de um elemento originariamente não indígena - a escola - vai sendo tornada Kiriri, ou seja, domesticada por este povo. Nesses termos, a escola

[...] é defendida como algo imprescindível para a luta indígena. As informações analisadas nas entrevistas indicam um víncu-

12. “O Patxohã é a língua pataxó (BOMFIM, 2012), resultado de um esforço coletivo entre os Pataxó para a retomada da sua língua mãe, a partir de um processo de política linguística de autoria, que se desenvolve desde os mais velhos e da mobilização entre a geração mais nova através da criação de um grupo de pesquisadores pataxó motivados pelo desejo de aprendê-la, tomaram como tarefa a pesquisa para a documentação e ensino da língua pataxó, através de um projeto empreendido por eles próprios, desencadeado em 1998 (CÉSAR, 2011). [...] Enquanto um dos espaços possíveis para a implementação de política linguística para o ensino do Patxohã, a escola tem sido uma aliada nesse processo como um lugar significativo, pois é através dela que a geração mais nova está aprendendo o Patxohã. Isso só pode ser possível porque as lideranças pataxó deram a importância devida e abraçaram esse sonho de poder ver as crianças falando a língua e valorizando a sua própria cultura. Atualmente, já existem, só entre os Pataxó da Bahia, 30 professores de Patxohã espalhados pelas aldeias através das secretarias municipais e estadual de educação, pois há uma dificuldade em relação a essa questão, pois grande parte desses professores não chegou a concluir o ensino médio ou ter uma formação específica para professores” (BOMFIM; SOUZA, 2013, p.149-150).

13. Segundo a autora, "a noção de domesticação é uma opção teórico-metodológica, que objetiva realizar uma inversão do discurso indigenista, na qual um elemento originariamente não indígena - a escola é, antes de qualquer coisa, tratada como item a ser domesticado e não como mero elemento domesticador". (CHATES, 2011, p. 228). 
lo entre escolarização indígena e autonomia indígena, principalmente quando se trata de burocracia. Normalmente, as referências à burocracia se direcionam aos entraves na nossa administração, ou seja, na gestão escolar. A escola indígena é defendida também enquanto espaço de encontro e de convivência, havendo uma diferenciação entre estes dois termos. Enquanto espaço de encontro, ou seja, de articulação entre os professores que querem trabalhar juntos em prol da escola e da educação Kiriri. Ao mesmo tempo, é vista como um espaço de convivência, que faz com que as pessoas, principalmente os jovens, possam se ver com mais frequência, se relacionar e namorar. Assim, se minimiza uma questão que o cacique aponta como um problema: o casamento entre indígenas e não-indigenas. A fala abaixo exemplifica a relação entre os conhecimentos internos e externos ao universo da aldeia: “A escola é um lugar aonde a gente pode encontrar um colega que queira trabalhar junto dentro da comunidade e fora da comunidade, [...] um ambiente agradável, [...] é um lugar pra gente aprender" (Entrevista com Zezinho, diretor das escolas do grupo Kiriri de Cantagalo, núcleo Araçá, abril de 2010). Nesta fala, a escola é apontada como espaço "fronteiriço". Desse modo, a domesticação da escola pode ser vista como algo concreto a partir do momento em que tal instituição reúne elementos presentes "dentro e fora da comunidade". (CHATES, 2011, p. 233-234).
Em nossa tese (SANTANA, 2015), inspirados por Gow, defendemos que a escola para os Tupinambá de Olivença se constitui como "idioma de parentesco". À semelhança dos Piro, mas também com distinções em relação a estes, a escola, nas narrativas Tupinambá, é evocada, em muitas situações, sempre em referência há um tempo em que seus parentes ou patrícios, como eles se referem, por não terem o domínio da leitura e da escrita, deixaram-se enganar por membros da elite local, tendo como consequência a perda de seus territórios e, consequentemente, a desorganização de seus modos de vida. A escola é, portanto, hoje, um lugar onde se deve construir tupinambá sabido. Mas não somente isso e talvez aqui esteja a distinção em relação ao que a escola significa para os Piro.

0 retorno ao passado, para os Tupinambá, tem duplo efeito: recorre-se a este para compreender os tempos difíceis, em que perderam seus territórios, mas também para atualizar novas relações, na medida em que rememorar o passado, os tempos dos antigos, dos índios bravos, "verdadeiros", signifıca em (re) construir esses laços, possibilitando que estes restabeleçam socialidades perdidas (VIEGAS, 2007; LARA, 2012), hoje evocadas como condição para estarem na cultura. Nesse sentido, o tornar-se sabi$\mathrm{do}^{14}$, como já tratamos acima, é atravessado por esse "duplo efeito", que significa tanto a compreensão da leitura e da escrita, mas,

14. Há outros casos etnográficos em que essa expressão aparece na relação dos índios com a escola. Segundo Mariana Paladino, para o caso de jovens Ticuna que experimentam a cidade, inclusive para estudar, o tornar-se sabido passa pela apreensão do mundo dos brancos. Dessa forma, "outro aspecto envolvido na escolha da cidade é a valorização desse âmbito como uma instância pedagógica em si mesma. Predomina a ideia de que viver ou passar um período na cidade faz a pessoa mais 'sabida', mais 'amadurecida', com uma 'visão mais ampla das coisas'. Acredita-se que, sobretudo, os mais jovens têm de apreender coisas dos brancos e, para isso, morar na cidade é a melhor forma de aprender. [...] A socialização das 
sobretudo, a compreensão da história e da memória Tupinambá, a valorização da cultura, do estar na cultura, da tradição, da língua, daquilo que é considerado como sendo "propriamente Tupinambá”, tendo que ser produzido constantemente na relação com os parentes. No limite, tornar-se sabido implica em sair em defesa do parentesco e na possibilidade de estar na cultura.

Santana (2015) demonstra como a escola tem se tornado o lugar não somente da "resistência cultural e de reprodução da ordem tradicional", como afirma Silva (2010) referindo-se ao caso Xerente. A escola tem sido o lugar mesmo de produção de cultura, de pessoa, de parente, de "retomada" da tradição e de atualização do que significa, para este povo, estar na cultura. Os Tupinambá entendem o conhecimento produzido e transmitido pela escola como sendo cultura, sobretudo aquele que está relacionado à história e à memória do próprio povo. 0 conhecimento é tornado cultura e, da mesma forma, a cultura é tornada conhecimento. Daí o porquê de se ensinar a cultura na escola, das aulas de cultura, da valorização da história Tupinambá, dos processos que expandem a escola para muitas comunidades e da centralidade que esta tem entre os Tupinambá (SANTANA, 2015).

\section{Considerações Finais}

Esperamos que este apanhado e esta discussão da literatura, que se tem produzido recentemente, tenha conduzido os lei- tores a concordar que é de grande relevância analisar, colocando em relação, tanto os modos como a educação escolar indígena têm se constituído e implementado no Brasil, como o modo com que tem sido incorporado ao debate da antropologia. De um lado, acompanhamos uma história recente em que as escolas têm crescido em número e em importância política para os indígenas no Brasil. Neste processo, a escola, marcada historicamente pelo esforço de "integração do índio à sociedade nacional”, passa a ser uma parte importante da política dos próprios indígenas, uma parte de sua vida em que temas como a definição das identidades indígenas, da cultura indígena, dos processos próprios de ensino e aprendizagem, dos conhecimentos indígenas, assim como processos de aparentamento e construção de coletivos, ganham o foco de atenção e da prática. De outro lado, vimos como esta escola, especifica e diferenciada, indígena, tem se tornado objeto de pesquisa e reflexão na antropologia, colocando em relevo estes tanto temas, de interesse em toda a etnologia, de modo muito particular, assim como agudo.

De modo enfático, entendemos que não é possível, hoje, no Brasil, entender as realidades indígenas e os modos como se constituem identidades indígenas, sem que se entenda o papel que a escola tem nesses processos. Assim sendo, enfatizamos a importância de estudos específicos sobre as práticas pedagógicas e as gestões da escola indígena, tendo em vista uma maior com-

crianças Ticuna também está vinculada a contextos e a situações espontâneas baseadas na imitação das tarefas e das atividades realizadas pelos pais e irmãos. Por isso, faz sentido a representação de que para aprender sobre o 'mundo dos brancos' viver no meio deles - a cidade - é o melhor método de aprendizado. A convivência e o trato cotidiano com os 'brancos' garantem também a aprendizagem do português. A experiência adquirida nessa convivência complementa, na visão dos estudantes Ticuna e os seus parentes, os conhecimentos recebidos nas instituições escolares” (PALADINO, 2006, p. 141 - 142). 
preensão dos modos como conhecimentos e práticas escolares ganham forma nas diversas experiências, inclusive, como propomos ser uma atividade de grande relevância para os antropólogos, para avaliação e debate das políticas públicas, nacionais, de educação escolar indígena com um olhar nas especificidades, tão frequentemente obliteradas pela hegemonia dos processos de cunho nacional. Mas enfatizamos, também, que as pesquisas em etnologia indígena - área do conhecimento atenta aos modos indígenas de construir pessoas e coletivos, às cosmopolíticas indígenas, aos modos indígenas de diferenciação, aparentamento e de conhecimento sobre o mundo -, não podem prescindir, hoje, de um olhar atento ao que se passa na escola. Seja para entender a escola que fazem os indígenas, seja para melhor entender o que é ser indígena hoje no Brasil, há que se olhar, dentre tantas outras coisas, para as práticas, as relações e os debates que estas escolas engendram hoje, o que deve ser feito tanto por pedagogos e estudiosos da educação quanto por antropólogos.

\section{Referências}

ALVARES, M. M. Kitoko Maxakali: a criança indígena e os processos de formação, aprendizagem e escolarização. Revista Anthropológicas, ano 8, v. 15(1), 2004.

ALVARES, M. M. Yãmiy, os espíritos do canto: a construção da pessoa na sociedade Maxakali. 1992. Dissertação (Mestrado em Antropologia Social) - IFCH/Unicamp, Campinas, 1992.

BELTRAME, C. B. Etnografia de uma escola Xikrin. 2013. 163f. Dissertação (Mestrado em Antropologia Social) - UFSCar, São Carlos-SP, 2013.

BERGAMASCHI, M. A. Interculturalidade nas práticas escolares indígenas e não indígenas. In: PA-
LADINO, M; CZARNY, G (Orgs.). Povos indigenas e escolarização: discussões para se repensar novas epistemes nas sociedades latino-americanas: Rio de Janeiro: Garamond, 2012.

BOMFIM, A. B. Patxohã, língua de guerreiro: um estudo sobre o processo de retomada da língua Pataxó. Dissertação (Mestrado em Estudos Étnicos e Africanos) - Faculdade de Filosofia e Ciências Humanas, Universidade Federal da Bahia, Salvador, 2012.

BOMFIM, A. B.; SOUZA, A. B. B. de. 0 valor de uma escola para Kitok a partir da memória histórica Pataxó. In: CÉSAR, A. L. S; COSTA, S. L. (Orgs.). Pesquisa e escola: experiências em educação indígena na Bahia. Salvador: Quarteto, 2013.

BRASIL, Plano Nacional de Educação (20142024), 2014.

BRUNO, L. Gestão da educação escolar indígena diferenciada: contradições, limites e possibilidades. Revista Brasileira de Estudos Pedagógicos, v. 92, n. 232, set/dez, 2011.

CÉSAR, A. L. S.; COSTA, S. L. Cartografia da educação indígena: relato de uma experiência de pesquisa intercultural e interétnica In: CÉSAR, A. L. S.; COSTA, S. L. (Orgs.). Pesquisa e escola: experiências em educação indígena na Bahia. Salvador: Quarteto, 2013.

CÉSAR, A. L. S. Lições de Abril: a construção da autoria entre os Pataxó de Coroa Vermelha. Salvador: EDUFBA, 2011.

CHATES, T. de J. A domesticação da escola Kiriri: um estudo com base na antropologia histórica. Revista Fórum Identidades, ano 5, v. 10, jul/dez, 2011.

CHATES, T. de J. A domesticação da escola na perspectiva Kiriri. In: CÉSAR, A. L. S.; COSTA, S. L. (orgs.). Pesquisa e escola: experiências em educação indígena na Bahia. Salvador: Quarteto, 2013.

COLLET, C. L. G. Ritos de civilização e cultura: a escola Bakairi. 2006. Tese (Doutorado em Antropologia Social) - PPGAS/Museu Nacional/UFRJ, Rio de Janeiro 2006. 
COLLET, C. L. G. Performance e transformação na escola indígena Bakairi. Revista da FAEEBA Educação e Contemporaneidade. v. 19. n. 33, jan/ jun, 2010.

COLLET, C. L. G. Interculturalidade e educação escolar indígena: um breve histórico. In: GRUPIONI, L. D. B. (Org.). Formação de professores indigenas: repensando trajetórias. Brasília: Ministério da Educação/Secretaria de Educação Continuada, Alfabetização e Diversidade, 2006b.

COLLET, C. L. G. Quero progresso sendo índio: o princípio da interculturalidade na educação escolar indígena. 2001. Dissertação (Mestrado em Antropologia Social), PPGAS/Museu Nacional/UFRJ, Rio de Janeiro, 2001.

COHN, C.; SANTANA, J. V. J de. Sobre escolas indígenas e sobre crianças indígenas: algumas reflexões. In: CÉSAR, A. L. S; COSTA, S. L (Orgs.). Pesquisa e escola: experiências em educação indigena na Bahia. Salvador: Quarteto, 2013.

COHN, C. A cultura na escola indigena. In: CARNEIRO DA CUNHA, M; CESARINO, P. (Orgs.). Politicas Culturais e povos indigenas: a escola e outros problemas. São Paulo, EdUNESP, 2015.

COHN, C. Educação escolar indígena: para uma discussão de cultura, criança e cidadania ativa. Revista Perspectiva. Florianópolis, v. 23, n. 2, p. 485-515, 2005.

DAL' B0, T. L. Constuindo pontes: o ingresso de estudantes indígenas na UFSCar: uma discussão sobre "cultura" e "conhecimento tradicional". 2010 Dissertação (Mestrado em Antropologia Socia) - PPGAS/UFSCar, São Carlos-SP, 2010.

D’ANGELIS, W. da R. Aprisionando sonhos: a educação escolar indigena no Brasil. Campinas, SP: Curt Nimuendajú, 2012.

FERREIRA, M. K. L. A educação escolar indigena: um diagnóstico crítico da situação no Brasil. In: SILVA, A. L.; FERREIRA, M. K. L. (Orgs.) Antropologia, História e Educação: a questão indígena e a escola. 2 ed. São Paulo: Global, 2001.
GIRALDIN, 0. Aculturação e interculturalidade no Brasil: duas faces (duas fases) de uma mesma moeda? In: ROCHA, L. M. [et al.]. Cidadania, interculturalidade e formação de docentes indígenas. Goiânia: Ed. da PUC Goiás, 2010.

GOMES, A. M. R. Prólogo. In: PALADINO, M.; CZARNY, G. (Orgs.). Povos indigenas e escolarização: discussões para se repensar novas epistemes nas sociedades latino-americanas: Rio de Janeiro: Garamond, 2012.

GOW, P. ¿Podia ler Sangama?: sistemas gráficos, linguaje y shamanismo entre los Piro (Perú Oriental). Revista da FAEEBA - Educação e Contemporaneidade, Salvador, v. 19, n. 33, 2010.

GOW, P. O parentesco como consciência humana: o caso dos piro. Mana, Rio de Janeiro , v. 3, n. 2, p. 39-65, 1997.

GOW, P. Da Etnografia à História: "Introdução" e "Conclusão" de of Mixed Blood: Kinship and History in Peruvian Amazônia. Cadernos de Campo, São Paulo, n. 14/15, p. 197-226, 2006.

GRUPIONI, L. D. B. Quando a antropologia se defronta com a Educação: formação de professores indios no Brasil. Revista Pró-posições. v. 24, n. 2(71), maio/ago, 2013.

GRUPIONI, L. D. B. Olhar longe, porque o futuro é longe: cultura, escola e professores indígenas no Brasil. 2008. 237f. Tese (Doutorado em Antropologia Social) - FFLCH./USP, São Paulo, 2008.

LARA, A. E. M. "Estar na cultura”: Os Tupinambá de Olivença e o desafio de uma definição de indianidade no Sul da Bahia. 2012. 135f. Dissertação (Mestrado em Antropologia Social) - PPGAS/Unicamp, Campinas- SP, 2012.

LOPES DA SILVA, A. Educação para a tolerância e povos indigenas no Brasil. In: GRUPIONI, L. D. B.; VIDAL, L.; FISCHMANN, R. (Orgs.) Povos indigenas e tolerância: construindo práticas de respeito e solidariedade. São Paulo: EDUSP, 2001.

LOPES DA SILVA, A.; GRUPIONI, L. D. B. (Orgs.). A temática indigena e a escola: novos subsídios para professores de $1^{\circ}$ e $2^{\circ}$ graus. 2 ed. São Paulo: Global; Brasilia: MEC: MARI:UNESCO, 1998. 
LOPES DA SILVA, A. A educação indígena entre diálogos interculturais e multidisciplinares: introdução. In: SILVA, A. L. da; FERREIRA, M. K. L. (Orgs.) Antropologia, História e Educação: a questão indígena e a escola. 2 ed. São Paulo: Global, 2001.

MAINARDI, C. 0 papel da escola no resgate cultural dos Tupi Guarani da Terra Indígena Piaçaguera -SP. Revista Pós em Ciências Sociais. v. 7, n. 14, jul./dez, 2010.

MAINARDI, C. Construindo proximidades e distanciamentos: etnografia Tupi Guarani da Terra Indígena Piaçaguera/SP. 2010. 96f. Dissertação (Mestrado em Antropologia Social) - PPGAS/UFSCar, São Carlos-SP, 2010.

MELIÀ, B. Ação Pedagógica e alteridade: por uma pedagogia da diferença. In: CONFERÊNCIA AMERÍNDIA DE EDUCAÇÃO, 1. Mato Grosso, 1997.

MELO, V. M. C. de; GIRALDIN, 0. Os Akwe-Xerente e a busca pela domesticação da escola. Revista Tellus, ano 12, n. 22, jan./jun, 2012.

NUNES, Â. Etnografia de um projeto de educação escolar indígena, idealizado por professores Xavante: dilemas, conflitos e conquistas. Revista Currículo sem Fronteiras, v. 10, n. 1, jan/jun, 2010.

PALADINO, M.; CZARNY, G. Interculturalidade, conhecimentos indigenas e escolarização. In: PALADINO, M.; CZARNY, G. (Orgs). Povos indígenas e escolarização: discussões para se repensar novas epistemes nas sociedades latino-americanas: Rio de Janeiro: Garamond, 2012.

PALADINO, M; ALMEIDA, N. P. Entre a diversidade e a desigualdade: uma análise das políticas públicas para a educação escolar indígena no Brasil dos governos Lula. Rio de Janeiro: Contra Capa Livraria/LACED - Museu Nacional/UFRJ, 2012.

PALADINO, M. Estudar e experimentar na cidade: trajetórias sociais, escolarização, e experiência urbana entre os jovens indígenas Ticuna, Amazonas. 2006. 352f. Tese (Doutorado em Antropologia Social) - PPGAS/Museu Nacional/UFRJ, Rio de Janeiro, 2006.
SANTANA, J. V. J. A produção dos discursos sobre cultura e religião no contexto da educação formal: o que pensam/querem os Kiriri de sua escola? 2007.Dissertação (Mestrado em Educação e Contemporaneidade) - UESB, Jequié-BA, 2007.

SANTANA, J. V. J. 0 que se quer com a diferença? Reflexões sobre educação escolar indigena específica, diferenciada e intercultural: o caso Kiriri. Mujimbo: Revista de Estudos Étnicos e Africanos, n. 1, p. 44-70, 2011.

SANTANA, J. V. J. "A letra é a mesma, mas a cultura é diferente": a escola dos Tupinambá de Olivença. 2015. Tese (Doutorado em Antropologia Social). PPGAS/Ufscar, São Carlos-SP, 2015.

SAMPAIO, J. A. L. 0 resgate cultural como valor: reflexões antropológicas sobre a formação de professores indigenas. In: GRUPIONI, L. D. B. (Org.). Formação de professores indígenas: repensando trajetórias. Brasília: Ministério da Educação/Secretaria de Educação Continuada, Alfabetização e Diversidade, 2006.

SILVA, J. A. F. Educação indígena na área Xerente: apropriação e reforço cultural. In: ROCHA, L. M. [et al.]. Cidadania, interculturalidade e formação de docentes indigenas. Goiânia: Ed. da PUC Goiás, 2010.

SILVA, M. F. da; AZEVEDO, M. M. Pensando as escolas dos povos indígenas no Brasil: o movimento dos professores indigenas do Amazonas, Roraima e Acre. In: LOPES DA SILVA, A; GRUPIONI, L. D. B. (Orgs.). A temática indígena e a escola: novos subsídios para professores de $1^{\circ}$ e $2^{\circ}$ graus. 2 ed. São Paulo: Global; Brasilia: MEC: MARI:UNESCO, 1998.

SOUZA, A. C. G. Escola e reafirmação étnica: o caso dos Pataxó de Barra Velha, Bahia. Dissertação (Mestrado em Ciências Sociais) - UFBA, Salvador -BA, 2001.

. Revisitando a história da escola indígena: da escola para índios à escola indígena. In: CÉSAR, A. L. S; COSTA, S. L. (Orgs.). Pesquisa e escola: experiências em educação indígena na Bahia. Salvador: Quarteto, 2013. 
TASSINARI, A. M. I. No bom da festa: o processo de construção cultural das famílias Karipuna do Amapá. São Paulo: EDUSP, 2003.

TASSINARI, A. M. I.; COHN, C. Escolarização indigena entre os Karipuna e Mebengokré-Xikrin: uma abertura para o outro. In: TASSINARI, A. M. I; GRANDO, B. S.; ALBUQUERQUE, M. A. dos S. (Orgs.) Educação indígena: reflexões sobre noções nativas de infância, aprendizagem e escolarização. Florianópolis: UFSC, 2012.

TASSINARI, A M. I. Escola indigena: novos horizontes teóricos, novas fronteiras de educação. In: SILVA, A. L.; FERREIRA, M. K. L. (Orgs.) Antropologia, História e Educação: a questão indígena e a escola. 2 ed. São Paulo: Global, 2001.

TASSINARI, A. M. I. A educação escolar indígena no contexto do Antropologia brasileira. Ilha Revista de Antropologia, v. 10, n. 1, p. 217-244, 2008.

VIEGAS, S. de M. Terra Calada: Os Tupinambá na Mata Atlântica do sul da Bahia. Rio de Janeiro: 7Letras, 2007.

VIEIRA, M. G. "A gente não faz mais guerra, agora a gente está pensando": xamanismo e educação escolar entre os Maxacali. Cadernos de Campos, São Paulo, n. 19, 2010. 


\section{RESUMO}

As conquistas legais obtidas pelos povos indígenas na luta pelo direito a uma educação escolar diferenciada são muito recentes. A partir da Constituição Federal de 1988, resultou um detalhamento de leis que anunciam e encaminham possibilidades para uma escola indígena específica, diferenciada, intercultural e bilíngue, reconhecendo o direito dos povos indígenas manterem suas identidades étnicas, fazendo uso de suas línguas maternas e processos próprios de aprendizagem. Para além do que o Estado passou a denominar de "escola indigena", buscamos, neste artigo, apresentar distintos "casos etnográficos" em que coletivos indígenas acionam a escola a partir de intencionalidades as mais diversas, informadas por suas epistemologias, regimes próprios de conhecimento e sociocosmologias que, no limite, acabam, por diferentes meios, domesticando a escola e produzindo enfrentamentos e novas demandas para com o Estado. Dessa forma, os modos como os indígenas se apropriam da escola produzem aproximações e afastamentos em relação às políticas que o Estado elabora para os povos indígenas, trazem consequências, tensões, desafios tanto para o Estado como para os coletivos indígenas e, do mesmo modo, para a Antropologia.

\section{PALAVRAS-CHAVE}

Antropologia. Interculturalidade. Escolas indígenas.

\section{ABSTRACT}

The legal gains made by indigenous peoples in the struggle for the right to a differentiated school education are very recent. From the Federal Constitution of 1988 on, there has been a breakdown of laws which advertise and forward possibilities for a specific, differentiated, intercultural and bilingual indigenous school, recognizing the right of indigenous peoples to maintain their ethnic identities, making use of their native languages and their own learning processes. Beyond what the state began to call "indigenous school", in this article, we aim at showing distinct "ethnographic cases" where indigenous groups trigger school from the most diverse intentions, informed by their epistemology, own knowledge and sociocosmology regimes, which, ultimately and by different means, end up controlling the school and producing confrontations and new demands to the state. Thus, the ways indigenous peoples get to possess the school produce approaches and deviations concerning the policies that the state prepares for indigenous peoples, and they also bring consequences, tensions, challenges both for the state and for the indigenous groups and, likewise, for the Anthropology.

\section{KEYWORDS}

Anthropology. Indian schools. Interculturalism.

Recebido em: 09/05/15

Aprovado em: 29/11/15 
